\title{
Characterizing the Site and Mode of Action of Dynorphin at Hippocampal Mossy Fiber Synapses in the Guinea Pig
}

\author{
Pablo E. Castillo, Paul A. Salin, Marc G. Weisskopf, and Roger A. Nicoll \\ Departments of Cellular and Molecular Pharmacology and Physiology, University of California at San Francisco, San \\ Francisco, California 94143-0450
}

\begin{abstract}
Extracellular field potential recordings from the CA3 region in guinea pig hippocampal slices were used to study the release and action of dynorphin at the mossy fiber synapse. Dynorphin $A(1-17)$ or U69593 inhibited mossy fiber synaptic responses in preparations in which the CA3 region was surgically isolated from the rest of the hippocampus. This inhibition was completely reversed by the $\kappa_{1}$ selective antagonist nor-BNI, thus establishing the presence of functional $\kappa_{1}$ receptors in CA3. Inhibitory effects of dynorphin on mossy fiber responses were unaltered in the presence of the $\mathrm{N}$ - or P-type $\mathrm{Ca}^{2+}$ channel blockers, $\omega$-CgTx or $\omega$-Aga IVA, respectively. This indicates that the action of dynorphin is independent of the particular type of $\mathrm{Ca}^{2+}$ channel that mediates transmitter release at the
\end{abstract}

mossy fiber terminal. Heterosynaptic inhibition of mossy fiber responses was observed in the presence of nifedipine, $\omega$-CgTx, or $\omega$-Aga IVA, indicating that dynorphin release does not depend specifically on $\mathrm{L}-, \mathrm{N}$-, or P-type $\mathrm{Ca}^{2+}$ channels. The blockade of heterosynaptic inhibition by the membranepermeant $\mathrm{Ca}^{2+}$ chelator EGTA-AM suggests the involvement of a slow $\mathrm{Ca}^{2+}$-dependent process in dynorphin release. On the basis of a variety of experimental evidence, we propose that the time course of heterosynaptic inhibition is determined primarily by the time course of clearance of dynorphin in the extracellular space.

Key words: dynorphin; $\kappa$ receptors; calcium channels; hippocampus; mossy fibers; opioid
The hippocampal mossy fibers contain high amounts of the opioid peptide dynorphin (Gall et al., 1981; McGinty et al., 1983; McLean et al., 1987; Terrian et al., 1988; Wagner et al., 1991). We have demonstrated previously in the guinea pig that repetitive stimulation of the mossy fibers releases dynorphin, which acts on presynaptic $\kappa_{1}$ receptors, resulting in long-lasting heterosynaptic inhibition of fast synaptic transmission (Weisskopf et al., 1993; Salin et al., 1995). This finding raises a number of issues. First, the presence of $\kappa_{1}$ receptors in stratum (s.) lucidum, the termination zone of the mossy fibers, is controversial (Wagner et al., 1991, 1992). Second, although there has been much research into the cellular mechanisms of action of dynorphin (Grudt and Williams, 1993; Johnson and North, 1993; Moore et al., 1994; Xie et al., 1994; Chen et al., 1995), its mechanisms of action at mossy fiber synapses are unclear.

A number of studies have found that dynorphin can inhibit both N-type (Werz and Macdonald, 1984; Gross and Macdonald, 1987; Moises et al., 1994) and L-type (Moises et al., 1994) $\mathrm{Ca}^{2+}$ channels. Our studies show that mossy fiber synaptic transmission is mediated by N- and P-type $\mathrm{Ca}^{2+}$ channels (Castillo et al., 1994b). This raises the possibility that the inhibitory effects of dynorphin at the mossy fiber synapse are mediated by blockade of a particular type of $\mathrm{Ca}^{2+}$ channel. In addition, there is evidence that the release of peptides, as distinct from the release of classical neurotransmitters, involves a high affinity $\mathrm{Ca}^{2+}$-dependent process

Received March 15, 1996; revised July 2, 1996; accepted July 8, 1996.

R.A.N. is supported by grants from National Institutes of Health, and P.E.C. is supported by the Fogarty International Center of National Institutes of Health. R.A.N. is a member of the Keck Center for Integrative Neuroscience and the Silvio Conte Center for Neuroscience Research. We thank Massimo Scanziani for critical comments on the diffusion model and Helen Czerwonka for help in preparing this manuscript.

Correspondence should be addressed to Roger A. Nicoll at the above address. Copyright (C) 1996 Society for Neuroscience $0270-6474 / 96 / 165942-09 \$ 05.00 / 0$ that is not restricted to the active zone (Burgoyne, 1991; Verhage et al., 1991). It has also been proposed that peptide release can be dependent on L-type $\mathrm{Ca}^{2+}$ channels (Perney et al., 1986; Cazalis et al., 1987; Rane et al., 1987; Hirning et al., 1988; Simmons et al., 1995). Is the release of dynorphin at the mossy fiber synapse dependent on particular types of $\mathrm{Ca}^{2+}$ channel? If the release of dynorphin depends on a high-affinity calcium-dependent process, one might predict that buffering intraterminal $\mathrm{Ca}^{2+}$ would prevent dynorphin release. Having an intact, synaptic function for endogenous dynorphin (i.e., heterosynaptic inhibition) also allows us to look at the dynamics of synaptically released dynorphin. What accounts for the duration of the heterosynaptic inhibition and how might the dynorphin be removed from the extracellular space? We know that peptides can act at a distance (Jan and Jan, 1982), but can a spatial concentration profile be determined? The present results demonstrate the presence of $\kappa_{1}$ receptors in the CA3 region and explore the role of different $\mathrm{Ca}^{2+}$ channel subtypes in the action and release of dynorphin. We also consider factors that determine the time course of heterosynaptic inhibition.

An abstract containing some of these results has been published (Castillo et al., 1994a).

\section{MATERIALS AND METHODS}

Hippocampal slices were prepared from 3- to 5-week-old Hartley guinea pigs (Castillo et al., 1994b). Animals were anesthetized with isoflurane and decapitated. The brain was rapidly removed and placed in cold, oxygenated mammalian artificial CSF. Hippocampi were dissected out and transferred to a slicing chamber. Transverse hippocampal slices $400-500 \mu \mathrm{m}$ thick were cut in the same ice-cold solution by a vibratome tissue slicer, placed in a holding chamber for at least $1 \mathrm{hr}$, and then transferred one at a time to a superfusing chamber for recordings. The superfusing solution contained (in mM): $119 \mathrm{NaCl}, 2.5 \mathrm{KCl}, 1.3 \mathrm{MgSO}_{4}$, $2.5 \mathrm{CaCl}_{2}, 26 \mathrm{NaHCO}_{3}, 1 \mathrm{NaH}_{2} \mathrm{PO}_{4}$, and 10 glucose and was equilibrated 


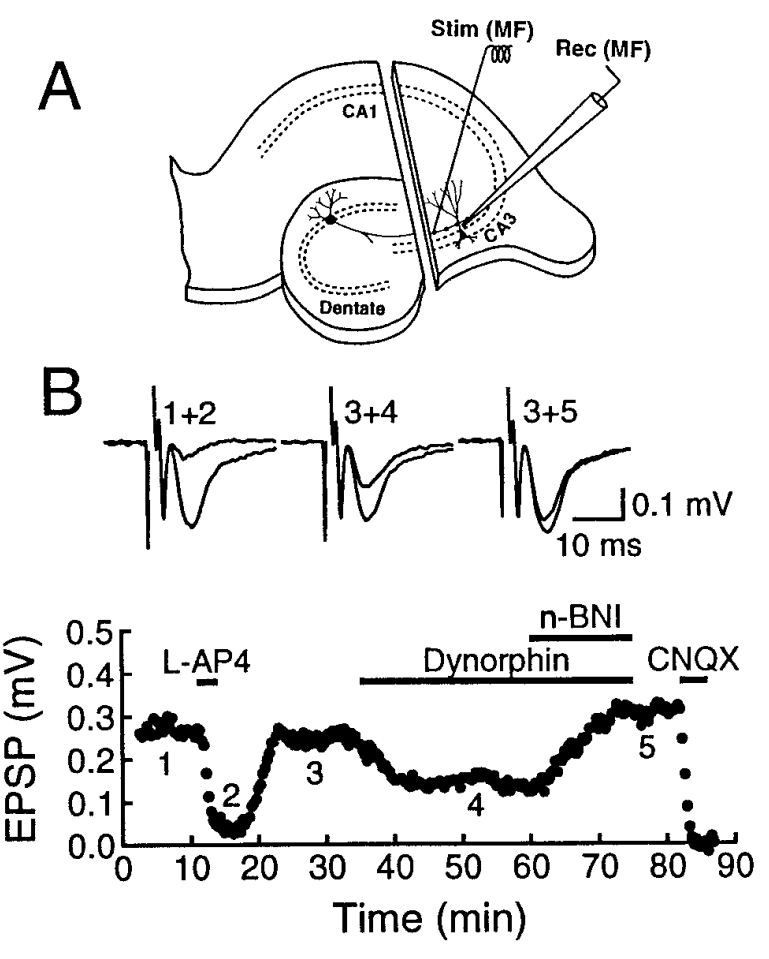

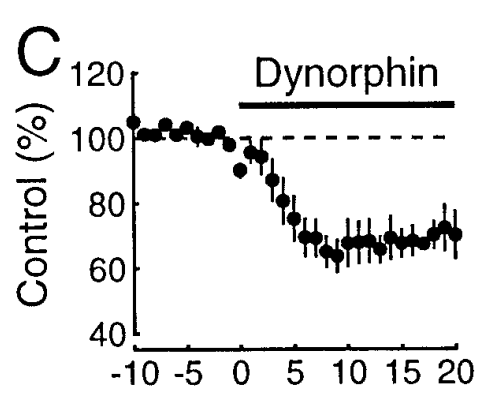

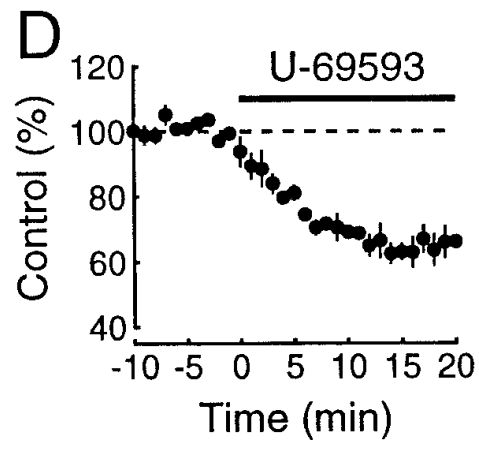

Figure 1. Dynorphin effect on mossy fiber synaptic transmission is mediated by $\kappa_{1}$ receptors at the CA3 region. $A$, Schematic diagram of the electrodes for stimulating and recording. The CA3 region was isolated from the rest of the hippocampus by using a surgical cut. To activate mossy fibers, we placed a stimulating electrode in the s. lucidum close to the extracellular recording electrode. $B$, Typical experiment showing the effect of dynorphin (500 nM) on an L-AP4sensitive $(10 \mu \mathrm{M})$ synaptic response and subsequent reversal by nor-BNI (300 nM). Sample superimposed traces from this experiment are shown on top. Each trace is the average of 10 individual responses. The numbers above the records correspond to the time at which they were taken, as indicated in the graph on the bottom. Note that the inhibitory effect of dynorphin occurs without any apparent change in the fiber volley amplitude. $C$, Summary of the dynorphin inhibitory effect using the same protocol as in $B(n=4)$. $D$, The $\kappa_{1}$ specific agonist, U-69593 (300 nM), also inhibits synaptic transmission in L-AP4-sensitive pathways recorded from isolated CA3 preparations $(n=3)$. with $95 \% \mathrm{O}_{2} / 5 \% \mathrm{CO}_{2}$. The flow rate was $1.5-2.5 \mathrm{ml} / \mathrm{min}$. Experiments were done at room temperature.

Field potential recordings were made with electrodes filled with $1 \mathrm{M}$ $\mathrm{NaCl}$. The restricted anatomy of the mossy fiber input as well as the reversal of the waveform as the recording electrode was moved from $\mathrm{s}$. lucidum to s. radiatum served to define mossy fiber inputs clearly. To obtain two independent mossy fiber pathways, two stimulating electrodes (bipolar stainless steel) were placed far apart in the granule cell layer of the dentate, and possible interaction between these two stimulating sites was tested routinely. The independence of the two pathways was verified by the lack of paired-pulse facilitation between the two pathways. An Axopatch-1D (Axon Instruments, Foster City, CA) was used to record the data. Responses were filtered at $2 \mathrm{kHz}$, digitized at $2-5 \mathrm{kHz}$ on a TL-1 interface (Axon Instruments), and collected on a microcomputer. A modified version of pClamp was used for analysis. At the end of all experiments, $20 \mu \mathrm{M}$ CNQX was added to the bath to assess the fiber volley component of the response. This component often could be a substantial fraction (up to 30\%) of the EPSP in response to the first of paired stimuli, especially after manipulation-induced depression. The fiber volley in CNQX then was subtracted from all responses. Baseline transmission was monitored with paired pulses given $40 \mathrm{msec}$ apart and repeated every $20-30 \mathrm{sec}$. To elicit heterosynaptic inhibition, a tetanus consisting of four trains of $100 \mathrm{~Hz}$ stimulation for $1 \mathrm{sec}$, separated by 20 sec, was given at baseline stimulus strength. All tetani were given in the presence of $25 \mu \mathrm{M}$ D-APV to avoid the induction of epileptic activity. All values are expressed as mean \pm SEM, except those in Figure $7 B$. Dynorphin was applied locally to s. lucidum by pressure (Picrospritzer II) from a microelectrode, the tip of which was broken to a diameter of $\sim 2 \mu \mathrm{m}$. To calculate the amount of dynorphin released, the tip of the electrode was placed in mineral oil and the identical pressure applied. The amount was then calculated from the volume of the bubble formed by the ejected fluid.

The cocktail of peptidase inhibitors contained (in $\mu \mathrm{M}$ ): 20 bestatin, 10 $N$-carboxy-phenyl-leucine, 2 Thiorphan, and 1 des-Tyr-Leu-Enkephalin. Drugs used were dynorphin A(1-17), dynorphin A(1-8), dynorphin B, $\alpha$-neoendorphin (Bachem, Torrance, CA); CNQX and norbinaltorphimine $2 \mathrm{HCl}$ (nor-BNI; Research Biochemicals, Natick, MA); D-APV (Tocris Cookson, Bristol, UK); nifedipine, $\omega$-CgTx GVIA, U69593, bestatin, $N$-carboxy-phenyl-leucine, thiorphan, des-tyr-leuenkephalin (Sigma, St. Louis, MO); $\omega$-Aga IVA (Peptides International, Louisville, KY); and EGTA-AM (Calbiochem, La Jolla, CA).

\section{RESULTS}

\section{Presence of $\kappa_{1}$ opioid receptors in the CA3 region}

To determine whether $\kappa_{1}$ receptors are localized in the CA3 region of the hippocampus, the effect of dynorphin on mossy fiber transmission was monitored in a slice in which this region was isolated with a surgical cut (Fig. 1). To activate the mossy fibers, a fine stimulating electrode was carefully positioned in s. lucidum, rather than in the dentate gyrus granule cell layer. Two procedures were used to record isolated mossy fiber responses that were not contaminated appreciably by stimulation of associational recurrent collaterals. First, to restrict stimulation to the mossy fiber bundle, the stimulus strength was reduced to approximately onetenth the strength used for dentate gyrus stimulation of mossy fibers. Second, the sensitivity of the synaptic responses to L-AP4, a metabotropic glutamate receptor agonist that selectively blocks mossy fiber responses (Yamamoto et al., 1983; Lanthorn et al., 1984; Weisskopf and Nicoll, 1995), was tested routinely (Fig. 1B). Responses were considered as mossy fiber responses if they were blocked at least $80 \%$ by L-AP4 $(10 \mu \mathrm{M})$.

Dynorphin (500 nM) inhibited the mossy fiber synaptic responses by $\sim 40 \%$ (Fig. $1 B, C$ ) without any change in the amplitude or waveform of the presynaptic fiber volleys. This inhibition is indistinguishable from that obtained in normal slices (Figs. $2 A$, $3 A$ ). Subsequent application of the selective $\kappa_{1}$ antagonist nor$\mathrm{BNI}$ reversed the dynorphin effect (Fig. $1 B$ ). In all experiments, unless otherwise stated, dynorphin A(1-17) was used. In addition, the selective $\kappa_{1}$ agonist U69593 also inhibited synaptic responses (Fig. 1D), indicating that functional $\kappa_{1}$ receptors are present in the CA3 region and mediate dynorphin inhibition of mossy fiber synaptic transmission.

\section{The role of $\mathrm{Ca}^{2+}$ channels in the action of dynorphin}

In normal extracellular bathing medium maximal concentrations of dynorphin cause a remarkably consistent inhibition of mossy fiber synaptic responses of $\sim 40 \%$ (Figs. $1 C, 3 A$ ), mediated by the 

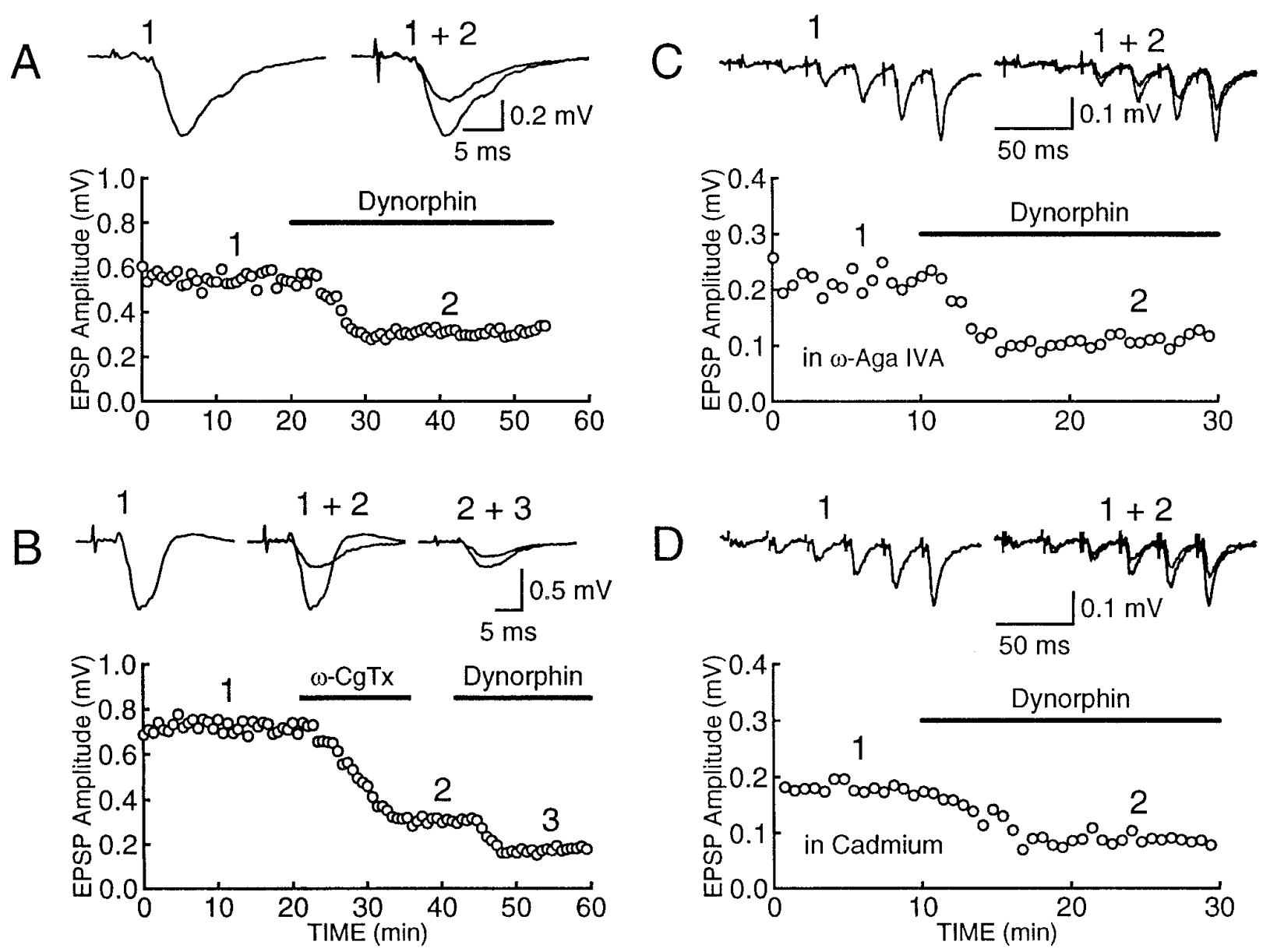

Figure 2. Effects of $\mathrm{Ca}^{2+}$ channel blockers on the inhibitory action of dynorphin on mossy fiber responses. Single experiments showing typical records of mossy fiber field potentials before and after addition of $500 \mathrm{~nm}$ dynorphin. The time course of the change in mossy fiber responses is depicted in the corresponding bottom panels. Each trace is an average of 10 synaptic responses. Dynorphin was applied in normal Ringer's solution $(A)$, after $1 \mu \mathrm{M} \omega$-CgTx $(B)$, after $1 \mu \mathrm{M} \omega$-Aga IVA $(C)$, or after $10 \mu \mathrm{M} \mathrm{CdCl}_{2}(D)$. Because $\omega$-Aga IVA almost completely blocked mossy fiber responses to single stimuli, a brief $25 \mathrm{~Hz}$ stimulation train was used to restore synaptic transmission and the inhibitory effect of dynorphin after $\omega$-Aga IVA or Cd ${ }^{2+}$ blockade of synaptic responses was assessed on the last response in the train.

activation of presynaptic opioid $\kappa_{1}$ receptors (Weisskopf et al., 1993). This ceiling effect raises the possibility that transmitter release may be controlled by multiple components and that dynorphin eliminates one of these components. Because mossy fiber synaptic transmission involves both $\mathrm{N}$ - and $\mathrm{P}$-type $\mathrm{Ca}^{2+}$ channels (Kamiya et al., 1988; Castillo et al., 1994b; Yamamoto et al., 1994), we tested whether the inhibitory action of dynorphin is altered after blockade of either of these channels. Figures $2 A$ and $3 A$ show the typical inhibition of mossy fiber responses in control conditions. As shown in Figure $2 B$, dynorphin is still capable of inhibiting mossy fiber responses after complete blockade of N-type $\mathrm{Ca}^{2+}$ channels with $\omega$-CgTx (Aosaki and Kasai, 1989; Plummer et al., 1989; Cox and Dunlap, 1992), and the magnitude of the inhibition $(39.5 \pm 3.1 \%, n=7$; Fig. $3 B)$ is not different from that obtained in control conditions $(38.6 \pm 4.2 \%, n=9$; Fig. $3 A)$. These findings indicate that $\mathrm{N}$-type $\mathrm{Ca}^{2+}$ channels are not necessary for the action of dynorphin. Next we examined the effect of dynorphin after blockade of P-type $\mathrm{Ca}^{2+}$ channels with $\omega$-Aga IVA (Mintz et al., 1992a,b). Because synaptic responses are very small in the presence of $1 \mu \mathrm{M} \omega$-Aga IVA, we took advantage of the marked frequency facilitation evoked by repetitive stimulation to restore synaptic transmission. This restored transmission is mediated by $\mathrm{N}$-type $\mathrm{Ca}^{2+}$ channels because it is completely blocked by $\omega$-CgTx (Castillo et al., 1994b). In the presence of $\omega$-Aga IVA, dynorphin is still capable of inhibiting the responses mediated by $\mathrm{N}$-type $\mathrm{Ca}^{2+}$ channels (Fig. $2 C$ ). To control for the use of repetitive stimulation to counteract the marked depressant effects of $\omega$-Aga IVA, we did the same experiments on responses that had been depressed to a similar extent with $10 \mu \mathrm{M}$ of the nonselective $\mathrm{Ca}^{2+}$ channel blocker cadmium. As can be seen in Figure $2 D$, dynorphin still had its inhibitory action, and the magnitude of the inhibition in the presence of $\omega$-Aga IVA (48.1 \pm $4.7 \%, n=6)$ and cadmium $(42.8 \pm 3.2 \%, n=6)$ was indistinguishable (Fig. $3 C$ ). These findings with $\mathrm{Ca}^{2+}$ channel blockers indicate that the magnitude of the inhibitory action of dynorphin on mossy fiber responses is independent of the particular type of $\mathrm{Ca}^{2+}$ channel mediating transmitter release. Therefore, dynorphin cannot be mediating its effects by reducing the current through a particular type of $\mathrm{Ca}^{2+}$ channel.

In a previous publication (Weisskopf et al., 1993) we reported that the action of dynorphin was enhanced when it was applied to synapses expressing LTP. We proposed that the N-type $\mathrm{Ca}^{2+}$ channel was a likely site for this interaction. The present results rule out a selective action of dynorphin on $\mathrm{N}$-type $\mathrm{Ca}^{2+}$ channels. We were therefore interested in reexamining the original observation because, if correct, it could provide insight into the mech- 

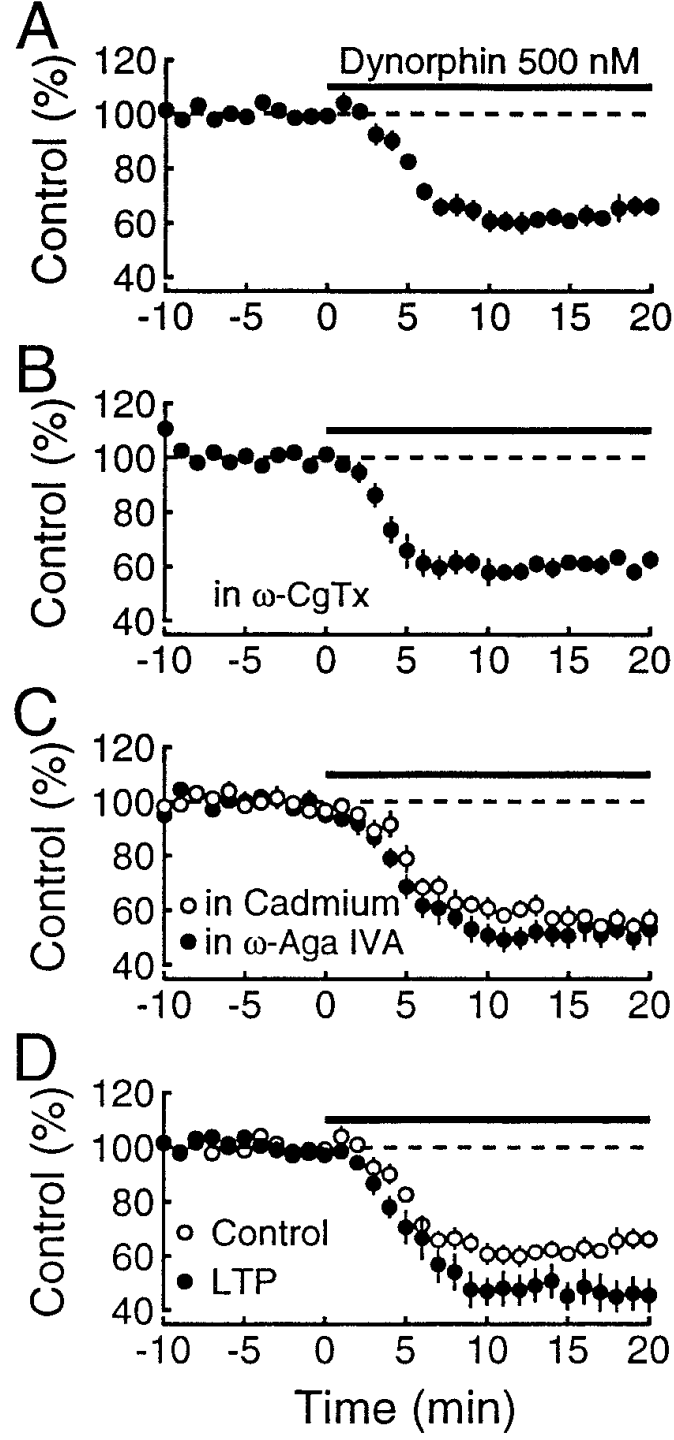

Figure 3. Inhibitory effect of dynorphin on mossy fiber synaptic transmission is not dependent on $\mathrm{N}$ - or P-type $\mathrm{Ca}^{2+}$ channels. Normalized field potentials are plotted against time. $A$, In control conditions, the reduction of mossy fiber responses $(n=9)$ by $500 \mathrm{nM}$ dynorphin was of similar magnitude to the reduction obtained by dynorphin after $\omega$-CgTx $(n=7)$ blockade of synaptic transmission $(B)$. $C$, In the presence of $\omega$-Aga IVA $(n=6)$ or $\mathrm{CdCl}_{2}(n=6)$, the effects of dynorphin on mossy fiber responses were also similar. $D$, Two separate pathways were monitored, and LTP was induced on one of the pathways. After the responses had stabilized (30-60 min), dynorphin was applied. The inhibition by dynorphin of the LTP-expressing pathway (filled circles) is greater than for the control pathway (open circles). These experiments indicate that the inhibitory effects of dynorphin on mossy fiber synaptic transmission is not dependent on $\mathrm{N}$ - or P-type $\mathrm{Ca}^{2+}$ channels, but it is influenced by LTP.

anism of action of dynorphin and LTP expression. In Figure $3 D$ two independent pathways were monitored, and LTP was induced on one of the pathways. After the LTP had stabilized, dynorphin was applied. As can be seen, the inhibitory action of dynorphin is greater on the pathway expressing LTP $(54.6 \pm 2.5 \%)$ versus the control pathway ( $44 \pm 2.5 \%, p<0.015$; paired $t$ test; $n=9$ ).

\section{The role of $\mathrm{Ca}^{2+}$ channels in the release of dynorphin}

Because the inhibitory action of dynorphin was unaltered by the $\mathrm{Ca}^{2+}$ channel blockers, we could address whether distinct $\mathrm{Ca}^{2+}$
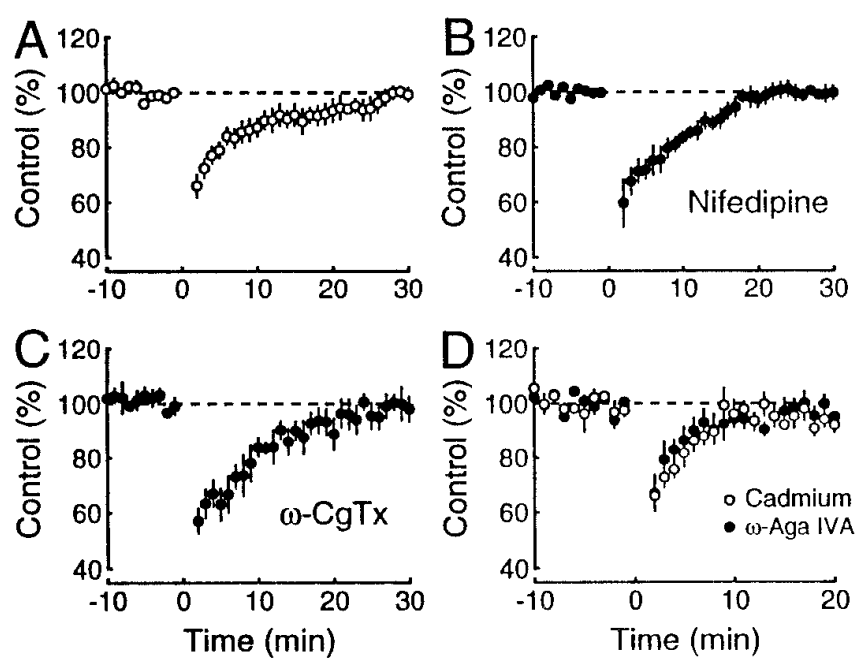

Figure 4. Dynorphin release is not associated with a specific presynaptic $\mathrm{Ca}^{2+}$ channel subtype. Two independent mossy fiber pathways were monitored. After baseline responses were stable for at least $10 \mathrm{~min}$, a tetanus was given in one pathway at time 0 . The mossy fiber field potentials of the untetanized pathway are plotted against time in normal Ringer's solution $(n=11 ; A), 30 \mu \mathrm{M}$ nifedipine $(n=5 ; B)$, and $1 \mu \mathrm{M} \omega$-CgTx $(n=6 ; C)$. The same was done for $1 \mu \mathrm{M} \omega$-Aga IVA $(n=4 ; D$, filled circles $)$ and $10 \mu \mathrm{M}$ $\mathrm{CdCl}_{2}(n=5 ; D$, open circles $)$; however, as in Figure 2, $C$ and $D$, a brief $25 \mathrm{~Hz}$ train was used to restore responses, and the amplitude of the responses to the last pulse was measured. These results indicate that neither the release nor the inhibitory effects of dynorphin depend on L-, $\mathrm{N}$-, or P-type $\mathrm{Ca}^{2+}$ channels.

channel subtypes are responsible for the release of dynorphin. Figure $4 A$ shows the magnitude and time course of the heterosynaptic inhibition observed in control experiments obtained during the course of the present set of experiments $(n=11)$. Nifedipine, a blocker of L-type $\mathrm{Ca}^{2+}$ channels, had no effect $(n=5)$ (Fig. $\left.4 B\right)$, suggesting that neither the release nor action of dynorphin is mediated via L-type $\mathrm{Ca}^{2+}$ channels. Heterosynaptic inhibition, similar to that observed in control experiments, could also be observed in the presence of $\omega$-CgTx $(n=6$; Fig. $4 C)$, indicating that $\mathrm{N}$-type channels are not required for the release of dynorphin. Finally, we recorded heterosynaptic inhibition in the presence of $\omega$-Aga IVA. As in Figure $2 C$, brief trains of stimuli were used to facilitate the responses. Although the duration of the inhibition was reduced $(n=4)$, heterosynaptic inhibition was still present in these conditions (Fig. $4 D$ ). To determine whether this reduction might be attributable to a specific effect of the $\omega$-Aga IVA or simply resulted from the marked depression of $\mathrm{Ca}^{2+}$ entry by $\omega$-Aga IVA, transmission was reduced to a similar extent with the nonselective $\mathrm{Ca}^{2+}$ channel blocker cadmium. The heterosynaptic inhibition was identical $(n=5$; Fig. $4 D)$, indicating that $\omega$-Aga IVA had no selective effect on heterosynaptic inhibition.

\section{Effect of intracellular $\mathrm{Ca}^{2+}$ buffering on heterosynaptic inhibition}

Because heterosynaptic inhibition persisted after the selective blockade of the known classes of presynaptic $\mathrm{Ca}^{2+}$ channels, the release of dynorphin clearly does not depend solely on one type of $\mathrm{Ca}^{2+}$ channel. If release of dynorphin is not restricted to the active zone in which $\mathrm{Ca}^{2+}$ entry is thought to occur, one might expect the buffering of $\mathrm{Ca}^{2+}$ in the presynaptic terminal to suppress heterosynaptic inhibition. We have used the membranepermeant buffer EGTA-AM, which is converted intracellularly into the active EGTA molecule. Application of EGTA-AM (200 
$\mu \mathrm{M})$ reduced fast synaptic transmission by $48.5 \pm 2.8 \%(n=6)$. This result is similar to that obtained at the crayfish neuromuscular junction (Winslow et al., 1994), but it is in contrast to the lack of effect of EGTA on transmitter release at the giant squid synapse (Adler et al., 1991). Formation of extracellular EGTA seems an unlikely explanation, because application of the same concentration of EGTA only caused a $15 \%$ depression. The buffer was clearly present in the terminals because paired-pulse facilitation, which is thought to be attributable to residual $\mathrm{Ca}^{2+}$, was reduced (Fig. $5 A$ ). In the presence of EGTA-AM, heterosynaptic inhibition was markedly depressed $(n=6$; Fig. $5 B)$. This depression was not simply attributable to the reduction in base line transmission, because an equivalent reduction in baseline transmission by $\omega$-CgTx (Fig. $4 C$ ) did not alter significantly the heterosynaptic inhibition. Furthermore, inhibition of mossy fiber responses by exogenously applied dynorphin was not reduced in the presence of EGTA-AM (Fig. 5C). Thus, the blockade of heterosynaptic inhibition is attributable to a reduction in dynorphin release rather than to a decrease in the action of dynorphin.

\section{Factors controlling the time course of heterosynaptic inhibition}

A number of factors could explain the prolonged time course of heterosynaptic inhibition. Dynorphin might be released for a prolonged period after the tetanic stimulation, or, once released, it might remain in the extracellular space for the duration of the response. Alternatively, dynorphin might be cleared quickly from the extracellular space, but the transduction mechanism after receptor binding has a long duration. If dynorphin were released only during the tetanus, one would expect that a brief puff of dynorphin from a puffer pipette placed in the s. lucidum would mimic the time course of heterosynaptic inhibition. This is shown in Figure $6 A$, in which the response to a puff of dynorphin $(n=6$; filled circles) is compared with the heterosynaptic inhibition $(n=$ 6; open circles). The similar time course of the inhibition evoked by the puff of dynorphin and heterosynaptic inhibition rules out prolonged release of dynorphin. If the time course is attributable to a prolonged transduction mechanism after the action of dynorphin at the receptors, rapid application of a receptor antagonist should not switch off the dynorphin response. Figure $6 B$ shows an example in which the inhibition induced by the bath application of dynorphin is unaffected by the rapid delivery of the $\kappa_{1}$ opioid receptor antagonist nor-BNI in the dentate gyrus but is rapidly reversed when the puff is delivered to the s. lucidum. A summary of eight such switch-off experiments is superimposed on the heterosynaptic inhibition in Figure $6 C$. It is clear that the switch-off of the action of dynorphin is faster than the heterosynaptic inhibition. Indeed, it is probably faster than the $5 \mathrm{~min}$ reversal of the action of dynorphin seen in Figure $6 C$, because this is likely to reflect, in part, the slow access of the antagonist to the receptors. Thus, the endogenous effect of dynorphin seems primarily to be dictated by the lifetime of this peptide in the extracellular space. We therefore considered the possibility that various peptidases (Chavkin et al., 1983; Schwartz et al., 1991) might influence the half-life of dynorphin in the extracellular space and examined the effect of prolonged incubation of slices in a cocktail of peptidase inhibitors on the heterosynaptic depression. However, these inhibitors had no effect either on the magnitude and time course of the heterosynaptic depression (Fig. 6D) or on the depression induced by low doses of dynorphin (Fig. 7 A, open circles). These results support the idea that the time course of heterosynaptic inhibition closely reflects the time course of free dynorphin in the
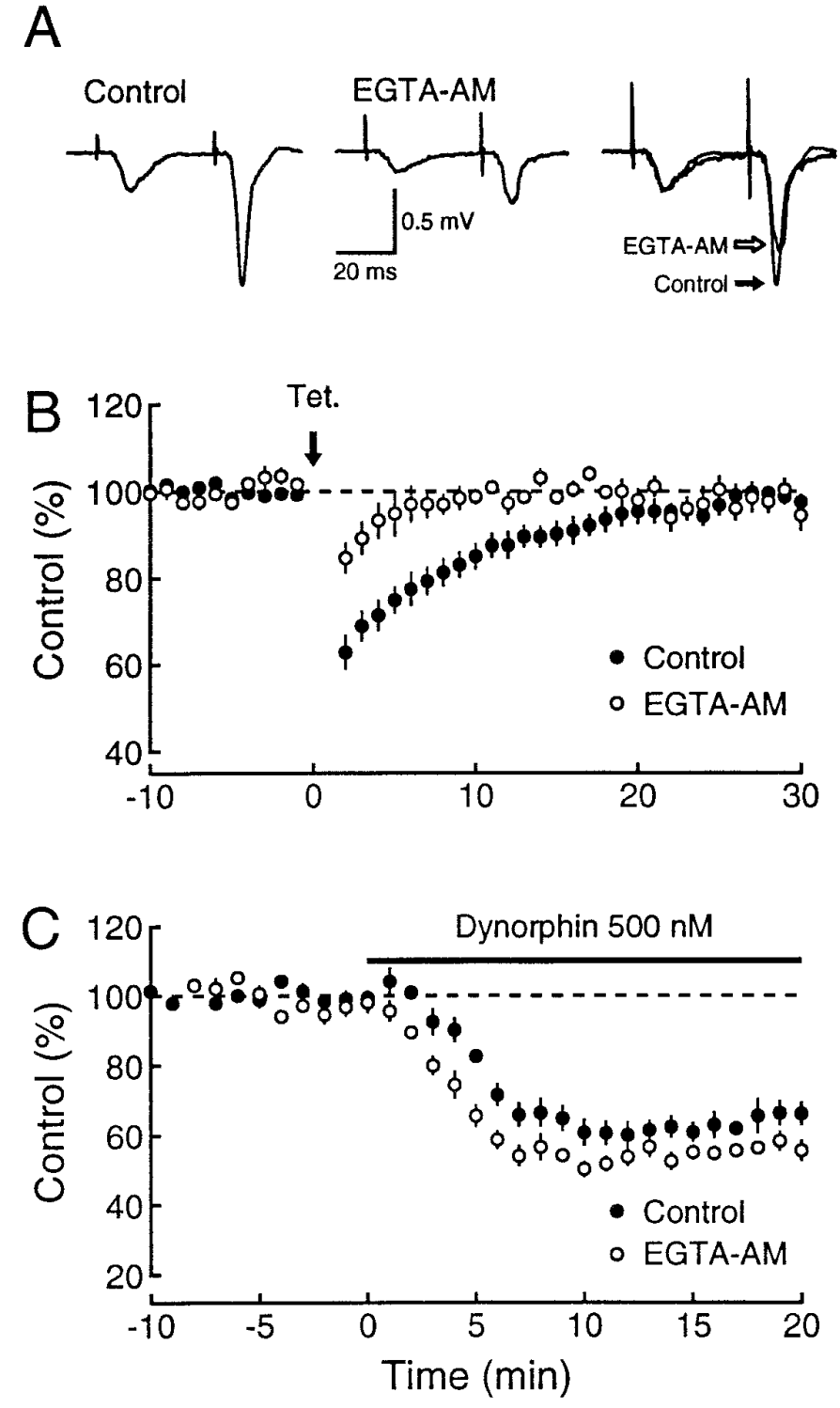

Figure 5. Intracellular buffering of residual free $\mathrm{Ca}^{2+}$ blocks dynorphin release. $A$, Typical records of mossy fiber field potentials before and after the addition of $200 \mu \mathrm{M}$ EGTA-AM. Each trace is an average of 10 synaptic responses. To compare the paired-pulse facilitation change, the mossy fiber response to the first pulse in EGTA-AM was scaled to the corresponding control response (right panel). $B$, Time course of heterosynaptic inhibition in control Ringer's solution $(n=11$; filled circles $)$ and in $200 \mu \mathrm{M}$ EGTA-AM ( $n=6$; open circles). EGTA-AM blocks heterosynaptic depression of mossy fiber transmission. For each set of data, the responses were normalized to $100 \%$. C, Dynorphin inhibition of mossy fiber synaptic responses is not blocked by EGTA-AM. The time course of $500 \mathrm{~nm}$ dynorphin reduction of synaptic transmission (Control; $n=9$; same data as plotted in Fig. $3 A$ ) is superimposed to that induced after $200 \mu \mathrm{M}$ EGTA-AM ( $n=3$; open circles). These results indicate that the EGTA-AM blockade of heterosynaptic depression is attributable to a reduction in dynorphin release rather than to a decrease in dynorphin effect.

extracellular space. If this hypothesis is true, a simple model assuming diffusion of dynorphin should mimic the time course of the heterosynaptic depression.

The following model assumes free diffusion of dynorphin in a three-dimensional space. On the basis of the similarities in the time course of inhibition after the puff application of dynorphin 

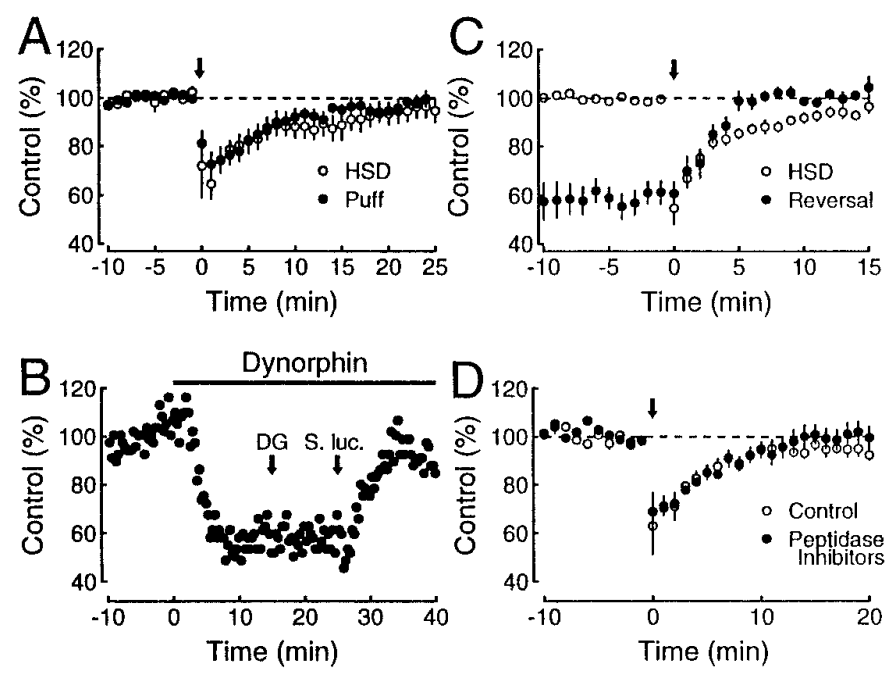

Figure 6. Time course of dynorphin action at the mossy fiber-CA3 pyramidal cell synapse. $A$, Five puff applications of $5 \mu \mathrm{M}$ dynorphin (200 $\mathrm{msec}, 200 \mathrm{kPa}$ ) at $1 \mathrm{sec}$ intervals given to the slice surface at the recording electrode in s. lucidum produces a transient depression $(n=6$; filled circles). The time course closely resembles that of tetanically induced heterosynaptic depression (HSD) from interleaved experiments $(n=6$; open circles). The time of each manipulation is indicated by the arrow. $B$, Mossy fiber synaptic responses were depressed with $500 \mathrm{~nm}$ dynorphin (bar). Five puff applications of nor-BNI (1 $\mu \mathrm{M}, 500 \mathrm{msec}, 200 \mathrm{kPa})$ separated by $1 \mathrm{sec}$ each given to the slice surface at the stimulating electrode in the dentate gyrus $(D G)$ had no effect on dynorphin-induced depression. The identical application given at the recording electrode in $\mathrm{s}$. lucidum 10 min later (S. luc.) rapidly reversed the depression. $C$, Rapid application of the $\kappa_{1}$ antagonist nor-BNI or naloxone was given at time 0 , as indicated by the arrow (filled circles). The application consisted of one of the following: (1) 5 puffs of $1 \mu \mathrm{M}$ nor-BNI at $1 \mathrm{sec}$ intervals $(n=2),(2)$ a drop of $50 \mu \mathrm{M}$ nor-BNI directly into the recording chamber $(n=3)$, or (3) 1-20 $\mu \mathrm{M}$ naloxone rapidly applied in the perfusion line $(n=3)$. No obvious difference was seen with these different modes of application. The effect of this application on mossy fiber synaptic responses depressed by $500 \mathrm{~nm}$ dynorphin is shown normalized to the steady-state level to which they returned. The reversal is faster than the time course of tetanically induced heterosynaptic depression $(H S D)$ from experiments performed concurrently $(n=12$; open circles $)$. $D$, Heterosynaptic depression was first induced under control conditions (open circles). After responses stabilized again, several peptidase inhibitors were added to the bath, which had no effect on baseline transmission. Heterosynaptic depression was subsequently induced again (filled circles), and no difference was seen $(n=8)$. The time of each tetanus is indicated by the arrow.

and the tetanus-induced heterosynaptic depression (Fig. 6A), we also assume that, during the tetanus, dynorphin is released from a point source. The free diffusion of dynorphin in a complex medium like the brain can be described by the three-dimensional Gaussian solution of Fick's principle (Nicholson and Phillips, 1981):

$$
C(r, t)=\frac{N}{\alpha} \frac{\lambda^{3}}{8(\pi D t)^{3 / 2}} \exp \left(\frac{-r^{2} \lambda^{2}}{4 D t}\right),
$$

in which $C$ is the extracellular concentration, $N$ is the quantity of dynorphin in mol, $r$ is the distance from the release site, $t$ is the time, $\lambda$ is the tortuosity, $\alpha$ is the volume fraction of the extracellular space, and $D$ is the free diffusion coefficient. The parameters $\alpha$ and $\lambda$ have been estimated for the CA3 region of the hippocampus, and they were equal to 0.155 and 1.71 , respectively (McBain et al., 1990). The diffusion coefficient of opioid peptides in water was estimated as $4 \times 10^{-6} \mathrm{~cm}^{2} / \mathrm{sec}$ (Gerhardt and Adams, 1982). Equation one describes the profile of dynorphin concentration through time and space after release. To determine the effect on mossy fiber responses of such variation of concentration, we experimentally constructed a dose-response curve for dynorphin $\mathrm{A}(1-17)$, dynorphin $\mathrm{A}(1-8)$, dynorphin $\mathrm{B}$, and $\alpha$-neoendorphin, the major peptides present in the mossy fiber terminals (Chavkin et al., 1983; Wagner et al., 1991). Steady-state responses were recorded to ensure adequate time for equilibration of the peptide in the slice, with different concentrations of a given peptide in the same slice. As shown in Figure $7 A$, concentrations as low as $10 \mathrm{~nm}$ of these peptides had an effect, and a maximal inhibition of $40 \%$ was reached at $\sim 500 \mathrm{~nm}$. The data were fit by curves drawn according to the logistic equation:

$$
y=\frac{y_{\max }-y_{\min }}{1+\left(\frac{x}{\mathrm{EC}_{50}}\right) n}+y_{\min },
$$

in which $x$ is the concentration and $y$ is the synaptic response amplitude. The rank order of agonist potencies was dynorphin $\mathrm{A}(1-17)$, dynorphin $\mathrm{B}, \alpha$-neoendorphin, and dynorphin $\mathrm{A}(1-8)$ with $\mathrm{EC}_{50}$ of $34 \pm 7 \mathrm{nM}(n=7), 56 \pm 9 \mathrm{nM}(n=5), 101 \pm 12 \mathrm{nM}$ $(n=6)$, and $272 \pm 11 \mathrm{~nm}(n=5)$, respectively. Dynorphin $\mathrm{B}$, the most abundant endogenous peptide present in mossy fibers (Chavkin et al., 1983), is as potent as dynorphin $\mathrm{A}(1-17)(p>$ 0.05; Student-Newman-Keuls test).

By combining equations one and two, the effect over time of brief dynorphin applications on mossy fiber responses was computed (Fig. $7 B$ ). It was assumed that there is a very small distance between release and recording sites. The $\mathrm{EC}_{50}$ values for dynorphin were obtained by curve fitting of the dose-response curve shown in Figure $7 A$. The three curves illustrated in Figure $7 B$, which were calculated for increasing quantities of dynorphin $\mathrm{A}$ $\left(10^{-15}, 10^{-14}\right.$, and $\left.10^{-13} \mathrm{~mol}\right)$, had increasingly longer time constants. The time course of the inhibition caused by the puff of dynorphin, shown by the filled circles, is close to the curve generated by the release of $10^{-13} \mathrm{~mol}$. However, measurements of the amount of dynorphin released during puffing experiments varied from $10^{-15}$ to $10^{-14} \mathrm{~mol}$ (see Materials and Methods). Given the close match between the time course of the puffinduced depression and the heterosynaptic depression (Fig. 6A), this modeling suggests that the long duration of heterosynaptic depression is unlikely to be explained only by free diffusion of dynorphin in the extracellular space.

\section{DISCUSSION}

We have described previously a dynorphin-mediated heterosynaptic inhibition of the release of glutamate from mossy fiber synapses in the guinea pig (Weisskopf et al., 1993). In the present study we have used this model system to examine a number of properties of peptidergic synaptic transmission.

\section{Functional $\kappa_{1}$ opioid receptors are present in the CA3 region of the hippocampus}

A controversy exists in the literature as to whether the $\kappa$ receptors present in the CA3 region are $\kappa_{1}$ or $\kappa_{2}$. On the basis of autoradiographic studies, it was reported that virtually no $\kappa_{1}$ receptor binding existed in the CA3 region of the guinea pig (Wagner et al., 1991, 1992); therefore, it was proposed that the $\kappa$ receptor binding observed previously in s. lucidum (McLean et al., 1987) reflected the binding to $\kappa_{2}$ receptors (Caudle et al., 1994). Our electrophysiological results, however, suggest the presence of functional $\kappa_{1}$ receptors in the CA3 region. The inhibitory effect induced by local puffing of dynorphin in the s. lucidum (Fig. $6 A$ ) suggests that this 

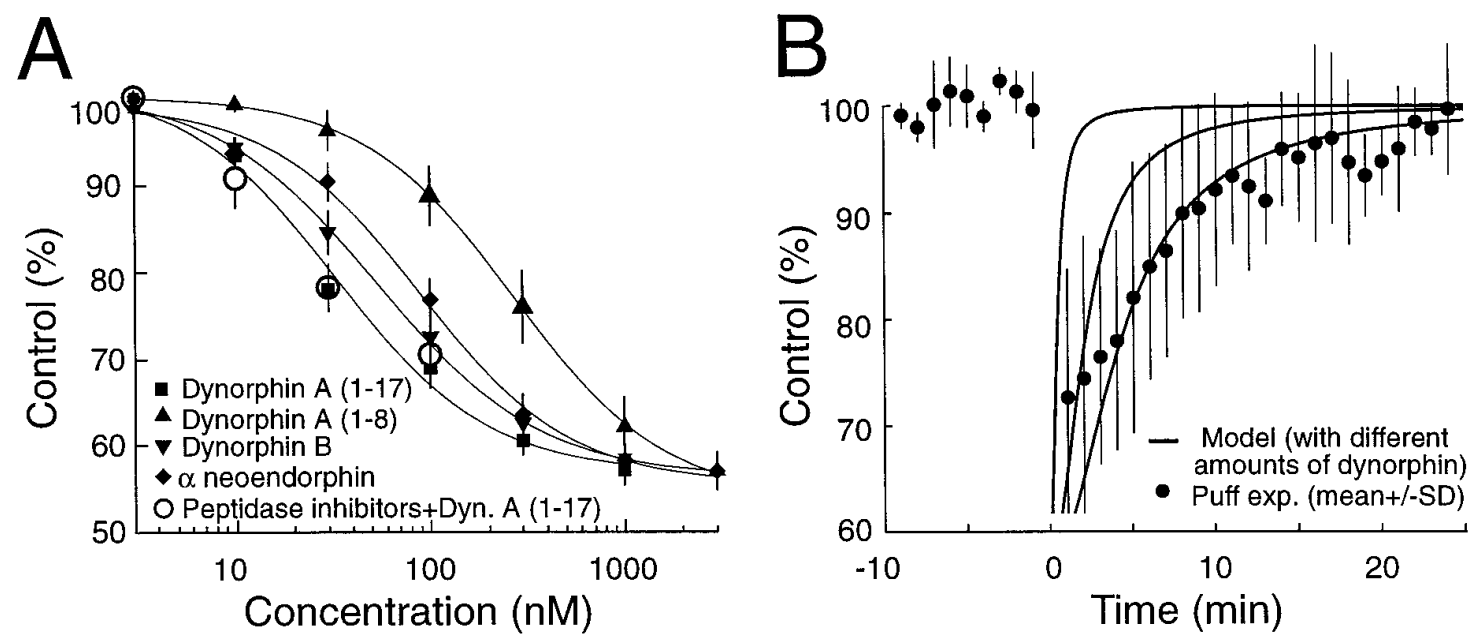

Figure 7. Relationship between time course of inhibition induced by puff application of dynorphin and free diffusion of dynorphin. $A$, Dose-response relationship of dynorphin A(1-17) (squares), dynorphin A(1-8) (up triangles), dynorphin B (down triangles), and $\alpha$-neoendorphin (diamonds) on mossy fiber responses. Each point represents the mean \pm SEM of four to seven experiments and is expressed as the percentage of depression of control responses. The fitting curves were drawn according to the logistic equation described in Results. Also shown is the lack of effect of a cocktail of peptidase inhibitors on the depression of mossy fiber responses induced by low concentration (10-100 nM) of dynorphin A(1-17) (open circles; $n=4)$. B, The time course of dynorphin action is represented by the filled circles $(n=6$; same data as the puff data in Fig. $6 A)$, and the family of curves was drawn according to a formula combining Fick's and logistic equations (see text).

action is localized to the CA3 region. In addition, dynorphin inhibition was reversed by selectively puffing nor-BNI in s. lucidum (Fig. 6B,C) and not s. granulosum (Fig. 6B). Because norBNI is a selective $\kappa_{1}$ antagonist, this indicates that dynorphin effects are indeed mediated by $\kappa_{1}$ receptors in the CA3 region. Finally, dynorphin and the selective $\kappa_{1}$ agonist U69593 were still able to inhibit mossy fiber synaptic responses in slices in which the CA3 region was completely isolated (Fig. 1). These experiments establish the presence of functional $\kappa_{1}$ receptors in the CA3 region of the hippocampus. Presumably, previous autoradiograpic studies (Wagner et al., 1991, 1992) lacked sufficient sensitivity to detect these receptors.

\section{The role of $\mathrm{Ca}^{2+}$ channels in the action and release of dynorphin}

We examined whether the $\kappa_{1}$ receptor-mediated presynaptic inhibitory action of dynorphin is targeted specifically to a class of $\mathrm{Ca}^{2+}$ channel. Fast synaptic transmission at mossy fiber synapses has been shown to depend on both $\mathrm{N}$ - and P-type $\mathrm{Ca}^{2+}$ channels (Castillo et al., 1994b), and under normal conditions mossy fiber responses are maximally inhibited by dynorphin by $40 \%$. Because it is well established that dynorphin can inhibit $\mathrm{Ca}^{2+}$ channels (Macdonald and Werz, 1986; Gross and Macdonald, 1987; Attali et al., 1989), one possible explanation for this ceiling effect is that dynorphin eliminates a particular type of $\mathrm{Ca}^{2+}$ channel. We were unable, however, to alter the magnitude of this inhibition by selectively blocking $\mathrm{N}$ - or P-type $\mathrm{Ca}^{2+}$ channels with either $\omega$-CgTx or $\omega$-Aga IVA (see also Simmons et al., 1995). These findings could be explained if dynorphin were to decrease action potential-dependent depolarization of the nerve terminal (e.g., by enhancing potassium currents). Alternatively, it could directly affect both types of $\mathrm{Ca}^{2+}$ channels to the same extent or inhibit transmitter release at a site after the entry of $\mathrm{Ca}^{2+}$. Any of these hypotheses would fit with existing evidence, because presynaptic inhibitory receptors can inhibit transmitter release both by inhibiting $\mathrm{Ca}^{2+}$ entry (Wu and Saggau, 1994, 1995; Dittman and Regehr, 1996) and by a more direct action on the secretory process (Scanziani et al., 1992; Scholz and Miller, 1992; Dittman and Regehr, 1996). Another alternative explanation for the partial inhibition by dynorphin is that there may be a heterogeneity among mossy fiber terminals such that only $40 \%$ of them are blocked completely by dynorphin. However, this would require that these two populations be distributed rather evenly in the granule cell layer, because the magnitude of the inhibition was remarkably constant from experiment to experiment. Previously, we reported that neither the induction nor the expression of mossy fiber LTP was altered by the blockade of N- or P-type $\mathrm{Ca}^{2+}$ channels (Castillo et al., 1994b). We have also confirmed previous results (Weisskopf et al., 1993) indicating that the inhibitory action of dynorphin is enhanced when it is generated on a pathway expressing LTP. This raises the interesting possibility that both LTP and dynorphin may act at some step after $\mathrm{Ca}^{2+}$ entry and that they act in opposite ways on the same process.

It is generally accepted that, although fast synaptic transmission occurs by the release of transmitter from the active zone by a low affinity $\mathrm{Ca}^{2+}$ sensor, peptide release is nondirected and occurs by a high affinity $\mathrm{Ca}^{2+}$ sensor (Burgoyne, 1991; Verhage et al., 1991). We have examined the effects of selective blockade of L-, N-, and P-type $\mathrm{Ca}^{2+}$ channels on the ability to evoke heterosynaptic inhibition and found that dynorphin release could occur in the absence of any one of these channels. These findings indicate that $\mathrm{Ca}^{2+}$ entry through either $\mathrm{N}$ - or P-type $\mathrm{Ca}^{2+}$ channels is adequate to initiate the release of dynorphin or that $\mathrm{Ca}^{2+}$ is not required for peptide release. Although $\omega$-CgTx exerted its usual inhibition of fast transmission in our study, it failed to alter the release of dynorphin, contrary to a recent study (Simmons et al., 1995) in which $\omega$-CgTx was reported to block synaptic release of dynorphin from mossy fibers.

To address further the role of $\mathrm{Ca}^{2+}$ in the release of dynorphin, we used EGTA-AM, a membrane-permeant $\mathrm{Ca}^{2+}$ chelator. Exposure of slices to EGTA-AM reduced paired-pulse facilitation, a phenomenon that depends on intraterminal residual $\mathrm{Ca}^{2+}$, thus indicating that free EGTA was present in mossy fiber terminals. Although EGTA-AM had no effect on the inhibitory action of dynorphin, heterosynaptic inhibition was severely depressed in 
these slices, demonstrating that the release of dynorphin requires a rise in $\mathrm{Ca}^{2+}$ in the mossy fiber terminal.

\section{Factors controlling the time course of heterosynaptic inhibition}

The long duration of heterosynaptic inhibition could result from a number of factors, such as prolonged release of dynorphin, prolonged presence of the peptide in the extracellular space, or prolonged second messenger activity. Brief puff application of dynorphin evoked an inhibition that had a time course remarkably similar to the response evoked by tetanization of mossy fibers, thus arguing against the possibility that dynorphin release continues after the tetanization. The finding that rapid application of a $\kappa_{1}$ receptor antagonist can reverse the action of dynorphin faster than the time course of the heterosynaptic inhibition indicates that dynorphin must remain present at the receptors throughout the synaptic response. The inability of a cocktail of peptidase inhibitors to alter either the heterosynaptic inhibition or the action of exogenously applied dynorphin argues against peptidases controlling the lifetime of dynorphin in the extracellular space, although we made no assay of the effectiveness of the inhibitors.

This leaves diffusion as the most likely regulator of the time course of heterosynaptic inhibition. We therefore modeled the characteristics of diffusion of dynorphin in the extracellular space to see whether we could simulate the time course of heterosynaptic inhibition. Maximal inhibition of mossy fiber responses to dynorphin, $\sim 40 \%$, occurred at a concentration of $100 \mathrm{nM}$. Immediately after the tetanus, heterosynaptic inhibition reached $40 \%$, suggesting that the minimal concentration of dynorphin in the extracellular space just after the tetanus is $100 \mathrm{~nm}$. The results of puff experiments (Fig. 6) suggest that the time course of heterosynaptic depression could be attributable to the clearance of dynorphin from the extracellular space. However, for the model to predict the duration of the dynorphin-mediated inhibition, a 10- to 100 -fold higher amount of dynorphin was required than was actually released from the pipette. This suggests that free diffusion alone is unlikely to account for the very long time course of heterosynaptic inhibition. One possibility is that the high affinity binding of dynorphin to $\kappa_{1}$ receptors buffers diffusion, as has been shown for acetylcholine at the neuromuscular junction (Katz and Miledi, 1973).

\section{Conclusion}

In summary, our results are consistent with a model in which dynorphin is released by a tetanus in a nondirected manner from mossy fibers and induces a heterosynaptic inhibition of neighboring mossy fiber synapses. The inhibition, which is attributable to a $\kappa_{1}$ receptor-mediated decrease in glutamate release, could result from an equal decrease in $\mathrm{Ca}^{2+}$ entry through $\mathrm{N}$ - and P-type $\mathrm{Ca}^{2+}$ channels or by an action subsequent to $\mathrm{Ca}^{2+}$ entry. The long duration of the inhibition is proposed to result from the continued presence of dynorphin in the extracellular space.

\section{REFERENCES}

Adler EM, Augustine GJ, Duffy SN, Charlton MP (1991) Alien intracellular calcium chelators attenuate neurotransmitter release at the squid giant synapse. J Neurosci 11:1496-1507.

Aosaki T, Kasai H (1989) Characterization of two kinds of high-voltageactivated Ca-channel currents in chick sensory neurons. Differential sensitivity to dihydropyridines and omega-conotoxin GVIA. Pflügers Arch 414:150-156.

Attali B, Saya D, Nah SY, Vogel Z (1989) Kappa opiate agonists inhibit $\mathrm{Ca}^{2+}$ influx in rat spinal cord-dorsal root ganglion cocultures. Involvement of a GTP-binding protein. J Biol Chem 264:347-353.
Burgoyne RD (1991) Control of exocytosis in adrenal chromaffin cells. Biochim Biophys Acta 1071:174-202.

Castillo PE, Weisskopf MG, Nicoll RA (1994a) Mechanisms of action of dynorphin at mossy fiber synapses. Soc Neurosci Abstr 20:60.

Castillo PE, Weisskopf MG, Nicoll RA (1994b) The role of $\mathrm{Ca}^{2+}$ channels in hippocampal mossy fiber synaptic transmission and long-term potentiation. Neuron 12:261-269.

Caudle RM, Chavkin C, Dubner R (1994) [Kappa $]_{2}$ opioid receptors inhibit NMDA receptor-mediated synaptic currents in guinea pig CA3 pyramidal cells. J Neurosci 14:5580-5589.

Cazalis M, Dayanithi G, Nordmann JJ (1987) Hormone release from isolated nerve endings of the rat neurohypophysis. J Physiol (Lond) 390:55-70.

Chavkin C, Bakhit C, Weber E, Bloom FE (1983) Relative contents and concomitant release of prodynorphin/neoendorphin-derived peptides in rat hippocampus. Proc Natl Acad Sci USA 80:7669-7673.

Chen L, Gu Y, Huang LY (1995) The opioid peptide dynorphin directly blocks NMDA receptor channels in the rat. J Physiol (Lond) 482:575-581.

Cox DH, Dunlap K (1992) Pharmacological discrimination of N-type from L-type calcium current and its selective modulation by transmitters. J Neurosci 12:906-914.

Dittman JS, Regehr WG (1996) Contributions of calcium-dependent and calcium-independent mechanisms to presynaptic inhibition at a cerebellar synapse. J Neurosci 16:1623-1633.

Gall C, Brecha N, Karten HJ, Chang KJ (1981) Localization of enkephalin-like immunoreactivity to identified axonal and neuronal populations of the rat hippocampus. J Comp Neurol 198:335-350.

Gerhardt G, Adams RN (1982) Determination of diffusion coefficients by flow injection analysis. Anal Chem 54:2618-2620.

Gross RA, Macdonald RL (1987) Dynorphin A selectively reduces a large transient (N-type) calcium current of mouse dorsal root ganglion neurons in cell culture. Proc Natl Acad Sci USA 84:5469-5473.

Grudt TJ, Williams JT (1993) Kappa-opioid receptors also increase potassium conductance. Proc Natl Acad Sci USA 90:11429-11432.

Hirning LD, Fox AP, McCleskey EW, Olivera BM, Thayer SA, Miller RJ, Tsien RW (1988) Dominant role of N-type $\mathrm{Ca}^{2+}$ channels in evoked release of norepinephrine from sympathetic neurons. Science 239:57-61.

Jan LY, Jan YN (1982) Peptidergic transmission in sympathetic ganglia of the frog. J Physiol (Lond) 327:219-246.

Johnson SW, North RA (1993) Presynaptic actions of opioids. In: Presynaptic receptors in the mammalian brain (Dunwiddie TV, Lovinger DM, eds), pp 71-86. Boston: Birkhäuser.

Kamiya H, Sawada S, Yamamoto C (1988) Synthetic omega-conotoxin blocks synaptic transmission in the hippocampus in vitro. Neurosci Lett 91:84-88.

Katz B, Miledi R (1973) The binding of acetylcholine to receptors and its removal from the synaptic cleft. J Physiol (Lond) 231:549-574.

Lanthorn TH, Ganong AH, Cotman CW (1984) 2-Amino-4phosphonobutyrate selectively blocks mossy fiber-CA3 responses in guinea pig but not rat hippocampus. Brain Res 290:174-178.

Macdonald RL, Werz MA (1986) Dynorphin A decreases voltagedependent calcium conductance of mouse dorsal root ganglion neurones. J Physiol (Lond) 377:237-249.

McBain CJ, Traynelis SF, Dingledine R (1990) Regional variation of extracellular space in the hippocampus. Science 249:674-677.

McGinty JF, Henriksen SJ, Goldstein A, Terenius L, Bloom FE (1983) Dynorphin is contained within hippocampal mossy fibers: immunochemical alterations after kainic acid administration and colchicineinduced neurotoxicity. Proc Natl Acad Sci USA 80:589-593.

McLean S, Rothman RB, Jacobson AE, Rice KC, Herkenham M (1987) Distribution of opiate receptor subtypes and enkephalin and dynorphin immunoreactivity in the hippocampus of squirrel, guinea pig, rat, and hamster. J Comp Neurol 255:497-510.

Mintz IM, Adams ME, Bean BP (1992a) P-type calcium channels in rat central and peripheral neurons. Neuron 9:85-95.

Mintz IM, Venema VJ, Swiderek KM, Lee TD, Bean BP, Adams ME (1992b) P-type calcium channels blocked by the spider toxin $\omega$-Aga IVA. Nature 355:827-829.

Moises HC, Rusin KI, Macdonald RL (1994) Mu- and kappa-opioid receptors selectively reduce the same transient components of highthreshold calcium current in rat dorsal root ganglion sensory neurons. J Neurosci 14:5903-5916. 
Moore SD, Madamba SG, Schweitzer P, Siggins GR (1994) Voltagedependent effects of opioid peptides on hippocampal CA3 pyramidal neurons in vitro. J Neurosci 14:809-820.

Nicholson C, Phillips JM (1981) Ion diffusion modified by tortuosity and volume fraction in the extracellular microenvironment of the rat cerebellum. J Physiol (Lond) 321:225-257.

Perney TM, Hirning LD, Leeman SE, Miller RJ (1986) Multiple calcium channels mediate neurotransmitter release from peripheral neurons. Proc Natl Acad Sci USA 83:6656-6659.

Plummer MR, Logothetis DE, Hess P (1989) Elementary properties and pharmacological sensitivities of calcium channels in mammalian peripheral neurons. Neuron 2:1453-1463.

Rane SG, Holz GGT Dunlap K (1987) Dihydropyridine inhibition of neuronal calcium current and substance $\mathrm{P}$ release. Pflügers Arch 409:361-366.

Salin PA, Weisskopf MG, Nicoll RA (1995) A comparison of the role of dynorphin in the hippocampal mossy fiber pathway in guinea pig and rat. J Neurosci 15:6939-6945.

Scanziani M, Capogna M, Gahwiler BH, Thompson SM (1992) Presynaptic inhibition of miniature excitatory synaptic currents by baclofen and adenosine in the hippocampus. Neuron 9:919-927.

Scholz KP, Miller RJ (1992) Inhibition of quantal transmitter release in the absence of calcium influx by a $\mathrm{G}$ protein-linked adenosine receptor at hippocampal synapses. Neuron 8:1139-1150.

Schwartz J-C, Bouthenet M-L, Giros B, Gros C, Llorens-Cortes C, Pollard H (1991) Neuropeptidases and neuropeptide inactivation in the brain. In: Volume transmission in the brain: novel mechanisms for neural transmission (Fuxe K, Agnati LF, eds), pp 381-394. New York: Raven.

Simmons ML, Terman GW, Gibbs SM, Chavkin C (1995) L-type calcium channels mediate dynorphin neuropeptide release from dendrites but not axons of hippocampal granule cells. Neuron 14:1265-1272.

Terrian DM, Johnston D, Claiborne BJ, Ansah-Yiadom R, Strittmatter WJ, Rea MA (1988) Glutamate and dynorphin release from a subcellular fraction enriched in hippocampal mossy fiber synaptosomes. Brain Res Bull 21:343-351.

Verhage M, McMahon HT, Ghijsen WE, Boomsma F, Scholten G, Wiegant VM, Nicholls DG (1991) Differential release of amino acids, neuropeptides, and catecholamines from isolated nerve terminals. Neuron 6:517-524.
Wagner JJ, Evans CJ, Chavkin C (1991) Focal stimulation of the mossy fibers releases endogenous dynorphins that bind kappa 1-opioid receptors in guinea pig hippocampus. J Neurochem 57:333-343.

Wagner JJ, Caudle RM, Chavkin C (1992) $\kappa$-Opioids decrease excitatory transmission in the dentate gyrus of the guinea pig hippocampus. J Neurosci 12:132-141.

Weisskopf MG, Nicoll RA (1995) Presynaptic changes during mossy fiber LTP revealed by NMDA receptor-mediated synaptic responses. Nature 376:256-259.

Weisskopf MG, Zalutsky RA, Nicoll RA (1993) The opioid peptide dynorphin mediates heterosynaptic depression of hippocampal mossy fiber synapses and modulates long-term potentiation. Nature 362:423-427.

Werz MA, Macdonald RL (1984) Dynorphin reduces calcium-dependent action potential duration by voltage-dependent calcium conductance. Neurosci Lett 46:185-190.

Winslow JL, Duffy SN, Charlton MP (1994) Homosynaptic facilitation of transmitter release in crayfish is not affected by mobile calcium chelators: implications for the residual ionized calcium hypothesis from electrophysiological and computational analyses. J Neurophysiol 72:1769-1793.

Wu LG, Saggau P (1994) Adenosine inhibits evoked synaptic transmission primarily by reducing presynaptic calcium influx in area CA1 of hippocampus. Neuron 12:1139-1148.

Wu LG, Saggau P (1995) GABA $_{B}$ receptor-mediated presynaptic inhibition in guinea pig hippocampus is caused by reduction of presynaptic $\mathrm{Ca}^{2+}$ influx. J Physiol (Lond) 485:649-657.

Xie GX, Meng F, Mansour A, Thompson RC, Hoversten MT, Goldstein A, Watson SJ, Akil H (1994) Primary structure and functional expression of a guinea pig kappa-opioid (dynorphin) receptor. Proc Natl Acad Sci USA 91:3779-3783.

Yamamoto C, Sawada S, Takada S (1983) Suppressing action of 2-amino-4-phosphonobutyric acid on mossy fiber-induced excitation in the guinea pig hippocampus. Exp Brain Res 51:128-134.

Yamamoto C, Sawada S, Ohno-Shosaku T (1994) Suppression of hippocampal synaptic transmission by the spider toxin $\omega$-agatoxin IVA. Brain Res 634:349-352. 